\title{
A RESEARCH REVIEW OF MOTIVATION-ENHANCING OF HUMAN RESOURCE PRACTICES
}

\author{
Nereida Hadziahmetovic, M. Sait Dinc, Kanita Jahic \\ International Burch University, Bosnia and Herzegovina
}

\begin{abstract}
This analysis of 115 articles about motivation-enhancing human resource practices published in seven Human Resource Management journals in a period between 2010 and 2015 presents significant contributions of individual scholars and institutions to research of motivation-enhancing human resource practices. Coauthor relationship is found through network analysis in order to show interrelationship among scholars who have contributed to this research. However, in order to provide main categories and subcategories in the field, authors carried out content analysis of the articles. Moreover, research locations, and methodologies of the articles are analyzed. Finally, to demonstrate recent trend of the research of motivation-enhancing human resource practices in the aforementioned period, this study provides some essential information such as number of articles published in each journal and in each year.
\end{abstract}

Keywords: Research of motivation-enhancing human resource practices, Human resource practices, Research topic, Research location, Research methodology, Scholar network.

DOI: http://dx.doi.org/10.15549/jeecar.v4i2.163

\section{INTRODUCTION}

In today's competitive business environment, only the best managed and the most efficient organizations can survive. Many different types of compensation and benefits have been used to attract, retain, and motivate employees and achieve organizational goals (Rynes and Gerhart, 2000; Barber and Bretz, 2000). Due to this reason, the research on the relationship between Human Resource Management (HRM) and various organizational outcomes has augmented in the past several decades; thus, researchers have started to examine why and how organizations achieve their goals through the use of human resource (HR) practices (Kaifeng, Lepak, Hu, and Baer, 2012). As a result, there has been a need for a systematic assessment of the contributions of researchers and academic and non-academic institutions to motivation-enhancing HR practices, demonstration of the interconnectedness of those contributions, and classification of the content of the articles.

This research review tries to meet the aforementioned need by identifying the researchers who have contributed to the motivation-enhancing $\mathrm{HR}$ practices and the institutions in which the research has been conducted. The review article also analyzes the content areas that have been studied over the period between 2010 and 2015 using the categorization found in Lepak and colleagues (2006) and Kaifeng et al. (2012) studies. Moreover, this study aims to present an inquiry and investigation of certain productive scholars and institutions by analyzing the network relationships among the authors. Finally, the authors attempt to present valuable information regarding the research of motivation-enhancing HR practices such as research locations, methodologies of the articles, number of articles published in each journal, and in each year. This 
review focuses on the publications in seven leading "HRM" journals, because most of the scholars who conduct research about motivation-enhancing HR practices publish their work in those outlets.

The contribution of this article to the motivation-enhancing HR practices research is apparent in several instances. First of all, this review identifies the authors who have made the largest contribution to the literature of motivation-enhancing HR practices based on the number of their papers published in some of the leading HRM journals, and the number of coauthors they have worked with. As it is shown in the analysis, a relatively small number of authors have dominated research in this area.

This study also introduces a list of the academic and non-academic institutions that have been the most dominant in supporting motivation-enhancing HR practices research. While majority of the previous review articles only provide information about the contribution of academic institutions to the researched field (Debicki, Matherne, Kellermanns, and Chrisman, 2009), this review identifies contributions of both academic and non-academic institutions. Findings of this article suggest that academic institutional support, in particular, is crucial for the development of research areas. The authors of the study present evidence of the contributions of academic and non-academic institutions to the research of motivationenhancing HR practices, and they hope to provide justification for the continuation and greater investment in the future.

Furthermore, the analysis of the topic areas that have been covered in this study about motivation-enhancing HR practices research will help in identification of research trends and areas needed for further scholars' investigation. Considering that these trends and gaps are related to the individuals, institutions, and networks involved in this research, this study hopes to encourage scholars to produce more publications in cooperation with other authors in order to fill the gaps in knowledge identified in this article. Furthermore, this study presents the connection between specific areas of research and the location where the research was conducted in order to show a detailed assessment.

Finally, through the list of countries, this study provides the analysis frequency of each country's practices that shows its perceived importance and interest. To receive an overall understanding, authors sorted countries based on continents as well. In addition to this, the analysis of methodologies used in the articles provides a list of frequently used methods, and explains the appropriateness of each method and the possible reasons for its usage. The analysis of the number of articles per year shows that an increase or a decrease in the number of publications can also be seen in motivation-enhancing HR practices research.

\section{METHOD}

In order to carry out the analysis, the authors identified and reviewed 115 articles about motivation-enhancing HR practices published in seven HRM journals in a period between 2010 and 2015.

Publications considered relevant to this study contained peer-reviewed articles. For the categorization of the articles, their titles, volumes and issue numbers, authors and their affiliation, and keywords were explored. Abstracts were also analyzed to determine the methodology, country, continent, and research field of each article.

\section{Individual and Institutional Research Productivity}

The research productivity of individuals and institutions was determined in the following ways. Initially, the authors determined the number of articles that each individual authored and coauthored. A list of all authors with more than one publication about motivationenhancing HR practices during the analyzed period is presented in Table 2 .

The impact factors of the Social Science Citation Index and h5 index were used to determine the quality of the publications. The journals' impact factors, h5-index, h5-median, and number of published articles about motivation-enhancing HR practices are presented in Table 1. Among 115 articles about motivation-enhancing HR practices published during the analyzed period, 50.4\% were published in The International Journal of Human Resource Management, whereas, another 42.6\% were published in the following four human resource management journals: Human Resource Management, Human Resource Management Journal, Human Relations, and Human Resource Management Review. 
Table 1. Journals' list: SSCI impact factor, h5-index, h5-median and number of published articles.

\begin{tabular}{lcccc}
\hline \multicolumn{1}{c}{ Journal } & $\begin{array}{c}\text { SSCI } \\
\text { Impact } \\
\text { Factor } \\
(2015)\end{array}$ & $\begin{array}{c}\text { h5 } \\
\text { index }\end{array}$ & $\begin{array}{c}\text { h5- } \\
\text { median }\end{array}$ & $\begin{array}{c}\text { Number } \\
\text { of } \\
\text { articles }\end{array}$ \\
\hline Human Resource Management & 1.8 & 36 & 51 & 13 \\
Human Resource Management Journal & 1.8 & 30 & 42 & 12 \\
Human Relations & 2.6 & 47 & 68 & 13 \\
Asia Pacific Journal of Human Resources & 0.8 & 18 & 24 & 4 \\
Human Resource Management Review & 2.2 & 35 & 55 & 11 \\
International Journal of Selection and Assessment & 0.6 & 20 & 26 & 4 \\
The International Journal of Human Resource Management & 1.3 & 46 & 61 & 58 \\
\hline Total & & & & 115 \\
\hline
\end{tabular}

Finally, institutional productivity scores were established by adding the individual journal publications that were adapted by coauthorship at an institutional level. To provide this information, this study recorded the primary institutional affiliation of the authors at the time in which the article was published.

\section{Network Analysis}

Co-authorship of research articles was analyzed in terms of networks formed by the authors. The authors reviewed 115 articles and coded names of authors to find the interrelationship among the most active scholars in the motivation-enhancing HR practices research. A detailed interpretation of the co-authorship network analysis is provided in the results section.

\section{Content Analysis}

The authors reviewed the articles and coded them according to four main categories and 61 subcategories classified by Lepak, Liao, Chung, and Harden (2006) and Kaifeng et al. (2012). These categories consisted of (a) skill-enhancing HR practices with 6 subcategories, (b) motivation-enhancing HR practices with 34 subcategories, (c) opportunity-enhancing HR practices with one subcategory, and (d) organizational outcomes with 20 subcategories.

\section{Research Location Analysis}

To account for the location of each research article, this study identified countries in which the research was conducted. The authors examined titles, keywords, and abstracts of the articles. The research locations of 80 among 115 articles were determined. In cases where articles' research was conducted in more than one country, authors coded those articles to each country separately. This was performed for six articles. To provide a more detailed assessment, a list of continents in which identified countries existed was presented.

\section{Methodology Analysis}

The titles and abstracts of the articles in motivation-enhancing HR practices research were analyzed to provide a list of the most frequently used research methods. In this way, research methods of 111 among 115 articles were identified. Articles that used more than one research method were coded separately according to each method. Disagreements in coding were resolved through the discussion with the third author. Overall, the following research methods utilized in reviewed articles were identified: (a) empirical research, (b) review, (c) case study analysis, (d) theoretical research, (e) conceptual paper, and (f) experiment.

\section{Year of Publication Analysis}

Finally, the authors reviewed and coded the articles in motivation-enhancing HR practices research published in a period between 2010 and 2015 according to their publication year. This approach has been employed in previous research (Handžić, 2015) to show the 
publication growth in the knowledge management field. With regard to this, a chart that displays the frequency of published articles in this field is provided.

\section{RESEARCH RESULTS}

\section{Ranking of Authors}

Table 2 presents the ranking of the most productive authors who have contributed to the research about motivation-enhancing HR practices with more than one article. After the analysis of 267 authors of 115 articles published in seven HRM journals, it has been revealed that the most productive scholar in a period between 2010 and 2015 is Gupta who published two articles in Human Resource Management Review and one article in Human Resource Management Journal. She is followed by 18 authors. The other 248 scholars are not mentioned in Table 2, because they published only one article during the analyzed period.

Table 2. Most Frequently Published Authors

\begin{tabular}{lc}
\hline Author & Publications \\
\hline Nina Gupta & 3 \\
Barry Gerhart & 2 \\
Bert Schreurs & 2 \\
Chun Hui & 2 \\
Cynthia Lee & 2 \\
Désirée Schumacher & 2 \\
Geoffrey Wood & 2 \\
Guy Notelaers & 2 \\
Hannes Guenter & 2 \\
I.J. Hetty van Emmerik & 2 \\
Jason D. Shaw & 2 \\
Kimberly K. Merriman & 2 \\
Kwok Leung & 2 \\
Meiyu Fang & 2 \\
Parbudyal Singh & 2 \\
Ramon Valle-Cabrera & 2 \\
Richard J. Long & 2 \\
Yoshio Yanadori & 2 \\
Zhaohong Lin & 2 \\
\hline
\end{tabular}

Ranking of Institutions

In previous studies, ranking of institutions according to their contributions to scientific fields has been analyzed in the fields such as marketing (Henry and Burch, 1976), and entrepreneurship (Shane, 1997). Similar reviews are completed to evaluate the effect of institutions on some other disciplines. For example, Debicki, Matherne, Kellermanns, and Chrisman (2009) ranked the contributions of institutions to family business research.

Table 3. The Most Operative Institutions

\begin{tabular}{lc}
\hline Institutions & $\begin{array}{c}\text { Public } \\
\text { ations }\end{array}$ \\
\hline Radboud University & 5 \\
Hong Kong Polytechnic University & 4 \\
University of Sheffield & 4 \\
The University of Hong Kong & 3 \\
University of London & 3 \\
University of Saskatchewan & 3 \\
Maastricht University & 3 \\
Monash University & 3 \\
Southwestern University of Finance & 3 \\
and Economics & 3 \\
University of Arkansas & 3 \\
University of British Columbia & 3 \\
University of Warwick & 2 \\
State University of New York & 2 \\
Texas A\&M University & 2 \\
Zhejiang University & 2 \\
University of Iowa & 2 \\
Concordia University & 2 \\
Curtin University & 2 \\
Finnish Institute of Occupational & 2 \\
Health & 2 \\
Michigan State University & 2 \\
Universidad Pública de Navarra & 2 \\
University of Houston-Victoria & 2 \\
University of Massachusetts Lowell & 2 \\
University of Toronto & 2 \\
University of Windsor & 2 \\
Vrije Universiteit Brussel & 2 \\
Yonsei University & 2 \\
York University & 2 \\
City University of Hong Kong & 2 \\
\hline & 2 \\
\hline
\end{tabular}

This study follows the approach of previous review articles by analyzing contributions to 
motivation-enhancing HR practices research carried out by different academic and nonacademic institutions. Table 3 displays the most operative institutions depending on the number of authors who contributed to the study of motivation-enhancing HR practices. In general, it has been found that 188 different institutions have supported 267 scholars, however, this study presented only 29 institutions with more than one article (Table 3). From Table 3 it can be interpreted that the Radboud University is the top ranked institution, followed by Hong Kong Polytechnic University, and University of Sheffield. Table 3 also displays 9 institutions that supported the publication of three articles, and 17 institutions that sponsored the publication of two articles. The number of institutions that contributed to the field with only one article during the analyzed period is 159.

Table 3 also displays academic and nonacademic institutions that contributed to the motivation-enhancing HR practices research. 28 institutions are academic institutions, while only one is a non-academic institution - Finnish Institute of Occupational Health. Figure 1 shows the distribution percentage of all analyzed institutions that supported the publication of the articles. The most active non-academic institution is the Finnish Institute of Occupational Health. Non-academic institutions include financial providers, consulting companies, institutes of science and technology, research institutes, and three banks.

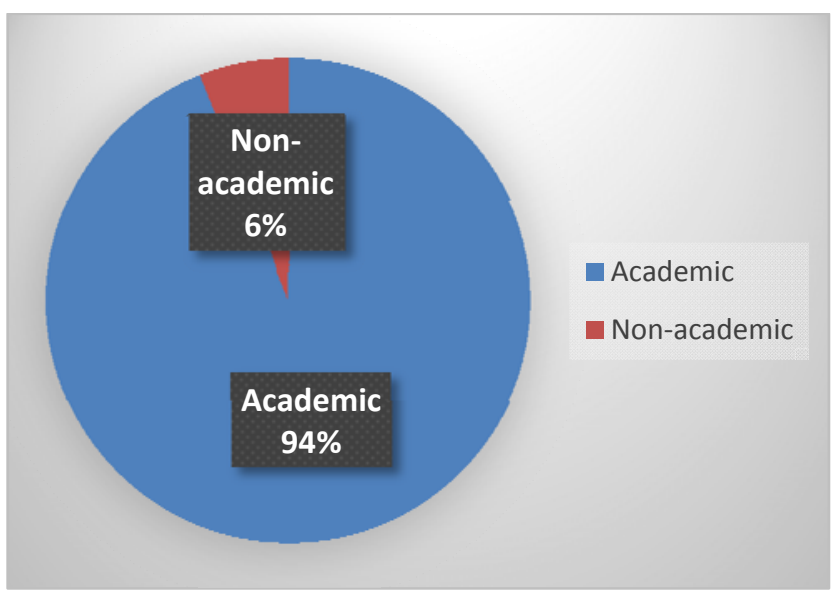

Figure 1. Percentage Distribution of Academic and Non-academic Institutions

\section{Co-authorship Network Analysis}

The interrelationships among the most active scholars in the research about motivationenhancing HR practices were presented in a diagram (see Figure 2). Debicki et al. (2009) prepared a similar diagram to show the interrelationships among the most engaged authors in family business research. The network diagram in this study concentrates on the connections between authors who have published two or more articles about motivation-enhancing HR practices. Coauthors who published less than two articles about motivation-enhancing $\mathrm{HR}$ practices are excluded from the diagram. Figure 2 also presents scholars who have published two or more articles about motivation-enhancing HR practices, but have no connection to other authors with similar productivity (two or more articles). They are displayed in the upper left corner in the figure.

The network approach shows different clusters of authors. The primary cluster includes 5 authors. As this diagram shows, authors such as Bert Schreurs are connected with many other scholars such as Desiree Schumacher, I. J. Hetty van Emerik, Guy Notelaers, and Hannes Guenter. Aside from this dominant cluster, diagram shows that there are three smaller coauthor networks that are connected based on the publication of more than two articles. These are the networks between Berry Gerhart and Meiyu Fang, Chun Hui and Cynthia Lee, and Nina Gupta and Jason D. Shaw. 
Geoffrey Wood

Kwok Leung

Parbudyal Singh

Ramon Valle-Cabrera

Richard J. Long

Zhaohong Lin
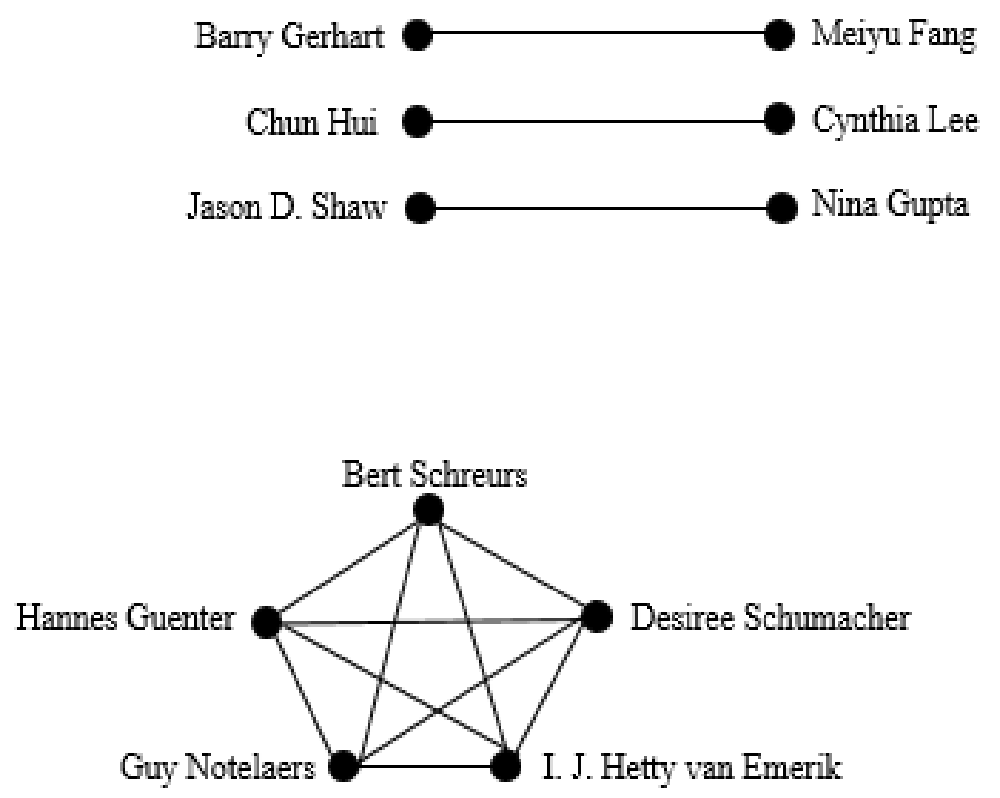

Figure 2. Co-authorship Network of Motivation-enhancing HR Practices Research (Two or More Publications per Author)

\section{Content Analysis}

After the abstract analysis of 115 articles in seven HRM journals, four categories were examined (see Table 4). The overall research activity with regard to primary categories of the articles is as follows: skill-enhancing HR practices (6.5\%), motivation-enhancing HR practices (24.4\%), opportunity-enhancing HR practices $(0.5 \%)$, and organizational outcomes (10.8\%). According to these results, motivation- enhancing $\mathrm{HR}$ practices and organizational outcomes are the most frequently studied topics followed by skill-enhancing HR practices. On the other hand, opportunity-enhancing HR practices are the least frequently studied categories.

In addition to nine main categories, 61 subcategories are shown in Table 4. Work motivation is the most frequently researched subcategory (9.3\%) followed by rewards (7.5\%), and job performance and productivity (5.1\%). 
Table 4. Categorization of Topics in the Research

\begin{tabular}{|c|c|c|c|c|}
\hline \multicolumn{2}{|l|}{ Topic Classification } & \multirow{2}{*}{$\begin{array}{l}\text { Subcategories } \\
\text { Work motivation }\end{array}$} & \multirow{2}{*}{$\frac{N}{20}$} & \multirow{2}{*}{$\begin{array}{l}\% \\
9.3\end{array}$} \\
\hline Motivation-enhancing HR & 1.1 & & & \\
\hline & 1.2 & Intrinsic motivation & 5 & 2.3 \\
\hline & 1.3 & Volunteering motivation & 2 & 0.9 \\
\hline & 1.4 & Career motivation & 1 & 0.5 \\
\hline & 1.5 & Learning motivation & 1 & 0.5 \\
\hline & 1.6 & Benefit schemes & 5 & 2.3 \\
\hline & 1.7 & Financial participation & 3 & 1.4 \\
\hline & 1.8 & Occupational pensions & 1 & 0.5 \\
\hline & 1.9 & Wages and salaries & 9 & 4.2 \\
\hline & 1.10 & Compensation system & 8 & 3.7 \\
\hline & 1.11 & Top management compensation & 5 & 2.3 \\
\hline & 1.12 & Expatriate compensation & 5 & 2.3 \\
\hline & 1.13 & Compensation fairness & 4 & 1.9 \\
\hline & 1.14 & Strategic compensation & 3 & 1.4 \\
\hline & 1.15 & Compensation criteria & 1 & 0.5 \\
\hline & 1.16 & Compensation importance & 1 & 0.5 \\
\hline & 1.17 & $\begin{array}{l}\text { Selective optimization with } \\
\text { compensation }\end{array}$ & 1 & 0.5 \\
\hline & 1.18 & Rewards & 16 & 7.5 \\
\hline & 1.19 & Combination of practices & 10 & 4.7 \\
\hline & 1.20 & Rewards and appraisal & 2 & 0.9 \\
\hline & 1.21 & Non-cash recognition & 2 & 0.9 \\
\hline & 1.22 & Payment for performance & 9 & 4.2 \\
\hline & 1.23 & Payment satisfaction & 6 & 2.8 \\
\hline & 1.24 & Payment dispersion & 3 & 1.4 \\
\hline & 1.25 & Variable payment & 3 & 1.4 \\
\hline & 1.26 & Choice of payment & 2 & 0.9 \\
\hline & 1.27 & Payment disparity & 2 & 0.9 \\
\hline & 1.28 & Payment reforms & 1 & 0.5 \\
\hline & 1.29 & Payment variation & 1 & 0.5 \\
\hline & 1.30 & Declared/undeclared payment & 1 & 0.5 \\
\hline & 1.31 & Ethnocentric payment policies & 1 & 0.5 \\
\hline & 1.32 & Group-based payment & 1 & 0.5 \\
\hline & 1.33 & Pay-personality relation & 1 & 0.5 \\
\hline & 1.34 & Payoff rules & 1 & 0.5 \\
\hline Skill-enhancing HR practices & 2.1 & Recruitment and selection & 1 & 0.5 \\
\hline & 2.2 & Training and development & 5 & 2.3 \\
\hline & 2.3 & Appraisal & 1 & 0.5 \\
\hline & 2.4 & Core self-evaluation & 2 & 0.9 \\
\hline & 2.5 & Skills and competencies & 5 & 2.3 \\
\hline & 2.6 & Employee's age & 4 & 1.9 \\
\hline $\begin{array}{l}\text { Opportunity-enhancing HR } \\
\text { practices }\end{array}$ & 3.1 & Knowledge-sharing motivation & 1 & 0.5 \\
\hline
\end{tabular}




\begin{tabular}{|c|c|c|c|c|}
\hline \multirow[t]{20}{*}{ Organizational outcomes } & 4.1 & Job performance and productivity & 11 & 5.1 \\
\hline & 4.2 & Job satisfaction & 5 & 2.3 \\
\hline & 4.3 & $\begin{array}{l}\text { Performance, commitment, } \\
\text { satisfaction, and turnover }\end{array}$ & 4 & 1.9 \\
\hline & 4.4 & Employee's innovation & 4 & 1.9 \\
\hline & 4.5 & Turnover intention & 3 & 1.4 \\
\hline & 4.6 & Affective commitment & 2 & 0.9 \\
\hline & 4.7 & Employee's autonomy & 2 & 0.9 \\
\hline & 4.8 & Employee's work quality & 2 & 0.9 \\
\hline & 4.9 & Salary productivity & 1 & 0.5 \\
\hline & 4.10 & Working attitudes & 1 & 0.5 \\
\hline & 4.11 & Organizational performance & 6 & 2.8 \\
\hline & 4.12 & Change in organizational size & 4 & 1.9 \\
\hline & 4.13 & Workplace bullying & 1 & 0.5 \\
\hline & 4.14 & Organizational citizenship behavior & 3 & 1.4 \\
\hline & 4.15 & Organizational communication & 2 & 0.9 \\
\hline & 4.16 & $\begin{array}{l}\text { Organizational psychological } \\
\text { contracts }\end{array}$ & 2 & 0.9 \\
\hline & 4.17 & Organizational employability & 2 & 0.9 \\
\hline & 4.18 & Organizational competency model & 1 & 0.5 \\
\hline & 4.19 & Organizational embeddedness & 1 & 0.5 \\
\hline & 4.20 & Organizational entrepreneurship & 1 & 0.5 \\
\hline
\end{tabular}

(Table 4. Continue)

\section{Research Location}

The authors of this study obtained information about research location of 80 among 115 articles based on their abstract and keywords. Table 5 presents a complete list of countries in which the research was conducted. Studies conducted in more than one country were coded to each country separately. This was carried out for six articles. According to a new coding, total number of articles raised up to 89 . Groups of the countries where the studies from these six articles were conducted are as follows: (a) Austria, Norway, Spain, and UK, (b) Canada and Australia, (c) China and Japan, (d) Lebanon and USA, (e) Russia, Armenia, and Kazakhstan, and (f) Spain and UK.

A list of continents where identified countries exist is presented in Table 5. As shown in this table, Europe is the most productive continent (40.4\%), followed by Asia (35.9\%), North and South America (12.3\%), Australia (10.1\%), and Africa (0.1\%). 
Table 5. Distribution of Published Articles Based on Location

\begin{tabular}{|c|c|c|}
\hline Continent & Country & Number of Articles \\
\hline \multirow[t]{17}{*}{ Europe } & Spain & 6 \\
\hline & UK & 5 \\
\hline & Belgium & 3 \\
\hline & Finland & 3 \\
\hline & Portugal & 3 \\
\hline & Norway & 3 \\
\hline & Holland & 2 \\
\hline & Italy & 2 \\
\hline & Turkey & 2 \\
\hline & Austria & 1 \\
\hline & Germany & 1 \\
\hline & Slovenia & 1 \\
\hline & South-Eastern Europe & 1 \\
\hline & Sweden & 1 \\
\hline & Greece & 1 \\
\hline & Denmark & 1 \\
\hline & Total & 36 \\
\hline \multirow[t]{15}{*}{ Asia } & China & 11 \\
\hline & Japan & 6 \\
\hline & India & 2 \\
\hline & Korea & 2 \\
\hline & Taiwan & 2 \\
\hline & Brunei Darussalam & 1 \\
\hline & Lebanon & 1 \\
\hline & Kazakhstan & 1 \\
\hline & Israel & 1 \\
\hline & Malaysia & 1 \\
\hline & Pacific Asia & 1 \\
\hline & Russia & 1 \\
\hline & Singapore & 1 \\
\hline & Armenia & 1 \\
\hline & Total & 32 \\
\hline \multirow[t]{3}{*}{ Australia } & Australia & 7 \\
\hline & New Zealand & 2 \\
\hline & Total & 9 \\
\hline \multirow[t]{3}{*}{ North America } & USA & 6 \\
\hline & Canada & 3 \\
\hline & Total & 9 \\
\hline \multirow[t]{3}{*}{ South America } & Mexico & 1 \\
\hline & Uruguay & 1 \\
\hline & Total & 2 \\
\hline \multirow[t]{2}{*}{ Africa } & Kenya & 1 \\
\hline & Total & 1 \\
\hline
\end{tabular}


As shown in Table 5, the country in Europe where the most studies are conducted is Spain with six articles, followed by United Kingdom with five articles. In Asia, the country with the greatest number of articles is China with 11 articles, followed by Japan with six articles. While Australia is the most productive country, with seven published articles in Australian continent, USA with six articles is a country where the greatest number of studies in motivation-enhancing HR practices field are conducted in North and South America, and Africa. In overall, China is the most productive country in this field during the analyzed period, followed by Australia, Spain, Japan, and USA.

Table 6 provides distribution of topic areas of HRM and continents. As shown in the table, all four categories in HRM are studied only in Europe, followed by Asia, North America, and Australia that lack a research about skill- enhancing $\mathrm{HR}$ practices and opportunityenhancing $\mathrm{HR}$ practices. According to the number of published articles in all four categories and continents distribution, Europe is the first continent, with 32 published articles in total, followed by Asia with 27 articles, and North America and Australia with 9 published articles. Africa and South America have the smallest number of published articles in each category.

With regard to the category of the most frequently studied topic per continent, it has been discovered that motivation-enhancing HRM practices is the most frequently studied topic with 21 published articles in Europe. It is one of the most frequently studied topics in Asia as well. In Europe and Asia, the second most frequently studied category is organizational outcomes, with 8 and 11 published articles respectively.

Table 6. Distribution of Topic Areas of the Research and Locations

\begin{tabular}{lcccc}
\hline Continent & $\begin{array}{c}\text { Motivation- } \\
\text { enhancing HR } \\
\text { practices }\end{array}$ & $\begin{array}{c}\text { Skill- } \\
\text { enhancing } \\
\text { HR practices }\end{array}$ & $\begin{array}{c}\text { Opportunity- } \\
\text { enhancing HR } \\
\text { practices }\end{array}$ & $\begin{array}{c}\text { Organizational } \\
\text { outcomes }\end{array}$ \\
\hline Europe & 21 & 2 & 1 & 8 \\
Asia & 16 & & & 11 \\
North America & 6 & & & 3 \\
South America & 2 & & & \\
Africa & 1 & & & 4 \\
Australia & 5 & & & \\
\hline
\end{tabular}

\section{Methodology Analysis}

The authors analyzed the titles and abstracts of the articles in motivation-enhancing HR practices research in order to present the list of the most commonly used research methods. Research methods of 111 among 115 articles were identified. According to review results, empirical research is a highly dominant method in conducting a research in this field (77\%). $10 \%$ of the articles used review method. The remaining four methodologies such as experiments, conceptual papers, theoretical researches, and case studies have same percentages of usage (3\%).

\section{Year of Publication Analysis}

Figure 3 shows the frequency of publications in the motivation-enhancing $\mathrm{HR}$ practices research in a period between 2010 and 2015 . This approach demonstrates the tendency for an increase or a decrease in the number of articles published in all seven journals. In a period between 2010 and 2012, there was a constant decrease in the number of published articles (20 articles in 2010, 18 articles in 2011, and 16 articles in 2012). The number of published articles started to increase with 2013 (18 articles), followed by 2014 (19 articles), and it reached the highest number in 2015 (24 articles).

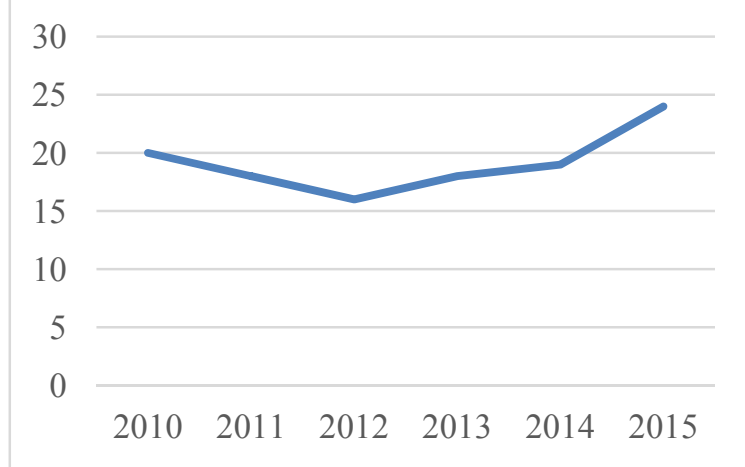

Figure 3. Number of Published Articles per Year 


\section{DISCUSSION}

This study identified the individuals and academic and non-academic institutions that have contributed the most to the research about motivation-enhancing HR practices in a period between 2010 and 2015 as well as the topics of interest examined by the authors. As expected, the publication of motivation-enhancing HR practices research heavily ascended particularly in the following journals: The International Journal of Human Resource Management, Human Resource Management, Human Resource Management Journal, Human Relations, and Human Resource Management Review. Although, the number of articles in this research area in the examined period is growing, this number is still relatively small as shown in Figure 3.

As the contributions of scholars and institutions are presented and the rankings are displayed in Tables 2 and 3, it appears that the research about motivation-enhancing HR practices is dominated by a relatively small number of authors from a relatively small number of institutions. These small groups suggest that continued efforts to expand the field should be supported by organizing some mainstream conferences. Even though, scholars currently seem to be working together in rather stable groups and publishing their work in some outlets, results of this study show that more collaboration is needed in motivationenhancing HR practices research among authors and institutions.

The results of the network analysis of the authorship that shows relationship among the scholars involved in the field, support the conclusions made by the authors and institutional contributions. Small clusters of authors suggest that the roles of journal editors and conference organizers seem particularly important due to the early stage of development and small size of the field. As expected, the results of this study show that academic institutions (i.e. universities) publish the highest number of articles. This research suggests that universities' role in promoting motivationenhancing $H R$ practices research needs to be strengthened. A research shows that research centers facilitate collaborations within a university (Boardman \& Corley, 2008). Considering that many successful universities have established research centers and the most prolific scholars are located at universities, centers should have a reinforcing effect on HRM motivation-enhancing HR practices research in particular. These centers can assist in the organization of the conferences in this research area. Thus, the motivation-enhancing HR practices network will be able to allow for more rapid knowledge diffusion throughout the research community. In the same way authors will be more aware of each other's research.

With regard to the content analysis of the study, this review of research areas revealed the most widely investigated issues in the HRM domain. Motivation-enhancing HR practices and organizational outcomes were the most common themes. Conversely, the analysis of the study revealed areas that have not been sufficiently examined, such as opportunityenhancing HR practices, and skill-enhancing HR practices.

\section{Limitations}

This article identifies the contributions of authors to motivation-enhancing HR practices research in a period between 2010 and 2015 . The approach of the study to assess individual and institutional contributions to this field is adapted from earlier approaches (Debicki et al., 2009; Handzic, 2015). However, there are some limitations of this study.

Firstly, this study concentrates on a research published in a period between 2010 and 2015 only. Due to the early stage of development of motivation-enhancing HR practices research, this seems appropriate. However, the research scope excludes a number of effective studies published before 2010. Future research may consider longer time periods.

The research analyzed 115 articles in seven HRM journals. The limited number of articles and journals could affect the results of the research. Therefore, future research could increase the number of articles and journals.

\section{CONCLUSION}

In conclusion, this study examined individual and institutional contributions to motivationenhancing HR practices research and the author networks that emerged in a period between 2010 and 2015. The content of the articles was also analyzed in seven journals. Through the identification of the scholars who conducted motivation-enhancing HR practices research, the research location, and most commonly used 
methods, this review aimed to provide a useful reference point for researchers and doctoral students at universities who are interested in HRM field of study. This research presented some emerging subcategories and research trends in HRM for scholars as well. Finally, this study provided useful productivity and journal quality benchmarks for scholars and institutions.

\section{REFERENCES}

Note: *indicates a source that was not included in the review.

Aletraris, L. (2010). How satisfied are they and why? A study of job satisfaction, job rewards, gender and temporary agency workers in Australia. Human Relations, 63(8).

Arrowsmith, J., Nicholaisen, H., Bechter, B., and Nonell, R. (2010). The management of variable pay in European banking. The International Journal of Human Resource Management, 21(15), 2716-2740. https://doi.org/10.1080/09585192.2010.528 654

*Backes-Gellner, U., and Pull, K. (2013). Tournament Compensation Systems, Employee Heterogeneity, and Firm Performance. Human Resource Management, 52(3), 375-398. https://doi.org/10.1002/hrm.21535

Bader, B. (2015). The power of support in highrisk countries: compensation and social support as antecedents of expatriate work attitudes. The International Journal of Human Resource Management, 26(13), 1712-1736.

https://doi.org/10.1080/09585192.2014.962 071

Balkin, D. B., Roussel, P., and Werner, S. (2015). Performance contingent pay and autonomy: Implications for facilitating extra-role creativity. Human Resource Management Review, 25(4), 384-395. https://doi.org/10.1016/j.hrmr.2015.07.001

*Barber, A. E., and Bretz, R. D., Jr (2000). Compensation, attraction, and retention. In S. L. Rynes and B. Gerhart (Eds.), Compensation in organizations (pp. 32-60). San Francisco, CA: Jossey-Boss.

Bayo-Moriones, A., Galdon-Sanchez, J. E., and Martínez-de-Morentin, S. (2013). The determinants of pay settlements: the influence of the national context. The International Journal of Human Resource Management, 24(3), 579-600. https://doi.org/10.1080/09585192.2012.694 110

Bello-Pintado, A. (2015). Bundles of HRM practices and performance: empirical evidence from a Latin American context: Bundles of HRM practices and performance. Human Resource Management Journal, 25(3), 311-330. https://doi.org/10.1111/1748-8583.12067

Beltrán-Martín, I., and Roca-Puig, V. (2013). Promoting Employee Flexibility Through HR Practices: Employee Flexibility. Human Resource Management, 52(5), 645-674. https://doi.org/10.1002/hrm.21556

Berber, P., Peters, P., Doorewaard, H., Eisinga, R., and Lagro-Janssen, A. L. M. (2014). Supporting "superwomen": conflicting role prescriptions, gender-equality arrangements and career motivation among Dutch women physicians. Human Relations, $672)$.

Bhatnagar, J. (2014). Mediator analysis in the management of innovation in Indian knowledge workers: the role of perceived supervisor support, psychological contract, reward and recognition and turnover intention. The International Journal of Human Resource Management, 25(10), 1395-1416. https://doi.org/10.1080/09585192.2013.870 312

Bipp, T. (2010). What do People Want from their Jobs? The Big Five, core self-evaluations and work motivation. International Journal of Selection and Assessment, 18(1), 28-39. https://doi.org/10.1111/j.14682389.2010.00486.x

*Boardman, P. C., and Corley, E. A. (2008). University research centers and the composition of research collaborations. Research Policy, 37, 900-913.

Bonsdorff, M. E. von. (2011). Age-related differences in reward preferences. The International Journal of Human Resource Management, 22(6), 1262-1276. https://doi.org/10.1080/09585192.2011.559 098

*Boxall, P., Hutchison, A., and Wassenaar, B. (2015). How do high-involvement work processes influence employee outcomes? An 
examination of the mediating roles of skill utilisation and intrinsic motivation. The International Journal of Human Resource Management, 26(13), 1737-1752.

https://doi.org/10.1080/09585192.2014.962 070

*Boxall, P., Hutchison, A., and Wassenaar, B. (2015). How do high-involvement work processes influence employee outcomes? An examination of the mediating roles of skill utilisation and intrinsic motivation. The International Journal of Human Resource Management, 26(13), 1737-1752. http://doi.org/10.1080/09585192.2014.9620 70

Carr, M. D., and Mellizo, P. (2013). The relative effect of voice, autonomy, and the wage on satisfaction with work. The International Journal of Human Resource Management, 24(6), 1186-1201. https://doi.org/10.1080/09585192.2012.706 818

Caza, A., McCarter, M. W., and Northcraft, G. B. (2015). Performance benefits of reward choice: a procedural justice perspective: Reward choice. Human Resource Management Journal, 25(2), 184-199. https://doi.org/10.1111/1748-8583.12073

Chambel, M. J., and Fortuna, R. (2015). Wage reduction of Portuguese civil servants and their attitudes: the psychological contract perspective. The International Journal of Human Resource Management, 26(22), 2853-2871.

https://doi.org/10.1080/09585192.2015.100 4099

Chang, E. (2011). Motivational effects of pay for performance: a multilevel analysis of a Korean case. The International Journal of Human Resource Management, 22(18), 3929-3948.

https://doi.org/10.1080/09585192.2011.561 248

Chen, C. C., Kraemer, J., and Gathii, J. (2011). Understanding locals' compensation fairness vis-à-vis foreign expatriates: the role of perceived equity. The International Journal of Human Resource Management, 22(17), 3582-3600. https://doi.org/10.1080/09585192.2011.560 873

Chien, M. S., Lawler, J. S., and Uen, J.-F. (2010). Performance-based pay, procedural justice and job performance for R\&D professionals: evidence from the Taiwanese high-tech sector. The International Journal of Human Resource Management, 21(12), 2234-2248. https://doi.org/10.1080/09585192.2010.509 626

Collings, D. G., Demirbag, M., Mellahi, K., and Tatoglu, E. (2010). Strategic orientation, human resource management practices and organizational outcomes: evidence from Turkey. The International Journal of Human Resource Management, 21(14), 2589-2613. https://doi.org/10.1080/09585192.2010.523 577

Conrad, H. (2011). Change and continuity in Japanese compensation practices: the case of occupational pensions since the early 2000s. The International Journal of Human Resource Management, 22(15), 3051-3067. https://doi.org/10.1080/09585192.2011.561 014

Cooke, F. L., and Huang, K. (2011). Postacquisition evolution of the appraisal and reward systems: A study of Chinese IT firms acquired by US firms. Human Resource Management, 506), 839-858. https://doi.org/10.1002/hrm.20457

Cortis, N., and Eastman, C. (2015). Salary sacrificing in Australia: are patterns of uptake and benefit different in the not-forprofit sector? Asia Pacific Journal of Human Resources, 53(3), 311-330. https://doi.org/10.1111/1744-7941.12054

Croucher, R., Brookes, M., Wood, G., and Brewster, C. (2010). Context, strategy and financial participation: a comparative analysis. Human Relations, 63(6), 835-855.

Curran, B., and Walsworth, S. (2014). Can you pay employees to innovate? Evidence from the Canadian private sector: Evidence from the Canadian private sector. Human Resource Management Journal, 24(3), 290306. https://doi.org/10.1111/17488583.12036

Debicki, B. J., Matherne, C. F., Kellermanns, F. W., and Chrisman, J. J. (2009). Family Business Research in the New Millennium: An Overview of the Who, the Where, the What, and the Why. Family Business Review, 22(2), 151-166. http://doi.org/10.1177/0894486509333598

De Gieter, S., and Hofmans, J. (2015). How reward satisfaction affects employees' 
turnover intentions and performance: an individual differences approach: Rewards and employee outcomes. Human Resource Management Journal, 25(2), 200-216. https://doi.org/10.1111/1748-8583.12072

Della Torre, E., Pelagatti, M., and Solari, L. (2015). Internal and external equity in compensation systems, organizational absenteeism and the role of explained inequalities. Human Relations, 68(3).

Diab, D. L., and Hazer, J. T. (2012). Effect of rater nationality on the relationships among ratee task, contextual, and counterproductive bebaviors and salary estimates. International Journal of Selection and Assessment, 20(3).

Díaz-Fernández, M., López-Cabrales, A., and Valle-Cabrera, R. (2013). In search of demanded competencies: designing superior compensation systems. The International Journal of Human Resource Management, 24(3), 643-666. https://doi.org/10.1080/09585192.2012.677 461

Downes, P. E., and Choi, D. (2014). Employee reactions to pay dispersion: A typology of existing research. Human Resource Management Review, 24(1), 53-66. https://doi.org/10.1016/j.hrmr.2013.08.009

Fabling, R., and Grimes, A. (2010). HR practices and New Zealand firm performance: what matters and who does it? The International Journal of Human Resource Management, 21(4), 488-508. https://doi.org/10.1080/0958519100361199 4

Faisal Ahammad, M., Mook Lee, S., Malul, M., and Shoham, A. (2015). Behavioral Ambidexterity: The Impact of Incentive Schemes on Productivity, Motivation, and Performance of Employees in Commercial Banks. Human Resource Management, 54(S1), s45-s62.

https://doi.org/10.1002/hrm.21668

Fallon, B. J., and Rice, S. M. (2015). Investment in staff development within an emergency services organisation: comparing future intention of volunteers and paid employees. The International Journal of Human Resource Management, 26(4), 485-500. https://doi.org/10.1080/09585192.2011.561 222

*Fang, M., and Gerhart, B. (2012). Does pay for performance diminish intrinsic interest?

The International Journal of Human

Resource Management, 23(6), 1176-1196. https://doi.org/10.1080/09585192.2011.561 227

Ferner, A., and Almond, P. (2013). Performance and reward practices in foreign multinationals in the UK: Performance and reward practices in MNCs. Human Resource Management Journal, 23(3), 241-261. https://doi.org/10.1111/1748-8583.12001

Foss, N. J., Pedersen, T., Reinholt Fosgaard, M., and Stea, D. (2015). Why Complementary HRM Practices Impact Performance: The Case of Rewards, Job Design, and Work Climate in a Knowledge-Sharing Context. Human Resource Management, 54(6), 955976. https://doi.org/10.1002/hrm.21649

Froehlich, D. E., Beausaert, S. A. J., and Segers, M. S. R. (2015). Age, employability and the role of learning activities and their motivational antecedents: a conceptual model. The International Journal of Human Resource Management, 26(16), 2087-2101. https://doi.org/10.1080/09585192.2014.971 846

Gerhart, B., and Fang, M. (2014). Pay for (individual) performance: Issues, claims, evidence and the role of sorting effects. Human Resource Management Review, 24(1), 41-52.

https://doi.org/10.1016/j.hrmr.2013.08.010

Gigliotti, M. (2013). The compensation of top managers and the performance of Italian firms. The International Journal of Human Resource Management, 24(4), 889-903. https://doi.org/10.1080/09585192.2012.702 317

${ }^{*}$ Gkorezis, P., and Petridou, E. (2012). The effect of extrinsic rewards on public and private sector employees' psychological empowerment: a comparative approach. The International Journal of Human Resource Management, 23(17), 3596-3612. https://doi.org/10.1080/09585192.2011.639 025

Goergen, M., O'Sullivan, N., and Wood, G. (2014). The consequences of private equity acquisitions for employees: new evidence on the impact on wages, employment and productivity: Consequences of private equity acquisitions for employees. Human Resource Management Journal, 24(2), 145- 
158. https://doi.org/10.1111/17488583.12032

Gupta, N., Conroy, S. A., and Delery, J. E. (2012). The many faces of pay variation. Human Resource Management Review, 22(2), 100115. https://doi.org/10.1016/j.hrmr.2011.12.001

Gupta, N., and Shaw, J. D. (2014). Employee compensation: The neglected area of HRM research. Human Resource Management Review, 24(1), 1-4. https://doi.org/10.1016/j.hrmr.2013.08.007

Hakonen, A., Maaniemi, J., and Hakanen, J. J. (2011). Why is group-based pay perceived as meaningful, meaningless or negative? Exploring the meanings of pay suggested by reflection theory. The International Journal of Human Resource Management, 22(10), 2245-2261. https://doi.org/10.1080/09585192.2011.580 194

*Handžić, M. (2015). A Descriptive Analysis of Knowledge Management Research: Period from 1997 to 2012. In E. Bolisani \& M. Handzic (Eds.), Advances in Knowledge Management(Vol. 1, pp. 45-64). Cham: Springer International Publishing. Retrieved from http://link.springer.com/10.1007/9783-319-09501-1_3

Hartmann, F., and Slapničar, S. (2012). Pay fairness and intrinsic motivation: the role of pay transparency. The International Journal of Human Resource Management, 23(20), 4283-4300. https://doi.org/10.1080/09585192.2012.664 962

Hayami, H., Nakamura, M., and Nakamura, A. O. (2012). Wages, Overseas Investment and Ownership: Implications for Internal Labor Markets in Japan (SSRN Scholarly Paper No. ID 2274984). Rochester, NY: Social Science Research Network. Retrieved from https://papers.ssrn.com/abstract $=2274984$

${ }^{*}$ Henry, W. R., and Burch, E. E. (1976). Market shares of space in marketing journals. Journal of the Academy of Marketing Science, 4, 473-483.

Hosie, P., Jayashree, P., Tchantchane, A., and Lee, B. S. (2013). The effect of autonomy, training opportunities, age and salaries on job satisfaction in the South East Asian retail petroleum industry. The International Journal of Human Resource Management,
24(21), 3980-4007. https://doi.org/10.1080/09585192.2013.829 517

Huang, T.-P. (2011). Comparing motivating work characteristics, job satisfaction, and turnover intention of knowledge workers and blue-collar workers, and testing a structural model of the variables' relationships in China and Japan. The International Journal of Human Resource Management, 22(4), 924-944. https://doi.org/10.1080/09585192.2011.555 134

Hui, C., Lee, C., and Wang, H. (2015). Organizational Inducements and Employee Citizenship Behavior: The Mediating Role of Perceived Insider Status and the Moderating Role of Collectivism. Human Resource Management, 54(3), 439-456. https://doi.org/10.1002/hrm.21620

Hytti, U., Kautonen, T., and Akola, E. (2013). Determinants of job satisfaction for salaried and self-employed professionals in Finland. The International Journal of Human Resource Management, 24(10), 2034-2053. https://doi.org/10.1080/09585192.2012.723 023

Jayasingam, S., and Yong, J. R. (2013). Affective commitment among knowledge workers: the role of pay satisfaction and organization career management. The International Journal of Human Resource Management, 24(20), 3903-3920. https://doi.org/10.1080/09585192.2013.781 520

*Jenkins Jr., G. D., Mitra, A., Gupta, N., and Shaw, J. D. (1998). Are financial incentives related to performance? A meta-analytic review of empirical research. Journal of Applied Pshychology, 83(5), 777-787.

*Kaifeng J., Lepak, D. P.,Hu, J., and Baer, J. C. (2012). How Does Human Resource Management Influence Organizational Outcomes? A Meta-Analytic Investigation of Mediating Mechanisms, Academy of Management Journal, Vol. 55, No. 6, 12641294.

Kalmi, P., Pendleton, A., and Poutsma, E. (2012). Bargaining regimes, variable pay and financial participation: some survey evidence on pay determination. The International Journal of Human Resource Management, 23(8), 1643-1659. 
https://doi.org/10.1080/09585192.2012.661 993

Kaya, N., Koc, E., and Topcu, D. (2010). An exploratory analysis of the influence of human resource management activities and organizational climate on job satisfaction in Turkish banks. The International Journal of Human Resource Management, 21(11), 2031-2051. https://doi.org/10.1080/09585192.2010.505 104

Kim, K., Oh, I.-S., Chiaburu, D. S., and Brown, K. G. (2012). Does Positive Perception of Oneself Boost Learning Motivation and Performance? International Journal of Selection and Assessment, 20(3), 257-271. https://doi.org/10.1111/j.14682389.2012.00598.X

Kooij, D. T. A. M., Jansen, P. G. W., Dikkers, J. S. E., and Lange, A. H. de. (2014). Managing aging workers: a mixed methods study on bundles of HR practices for aging workers. The International Journal of Human Resource Management, 25(15), 2192-2212. https://doi.org/10.1080/09585192.2013.872 169

Kuvaas, B., and Dysvik, A. (2010). Does best practice HRM only work for intrinsically motivated employees? The International Journal of Human Resource Management, 21(13), 2339-2357.

https://doi.org/10.1080/09585192.2010.516 589

Lange, T., Pacheco, G., and Shrotryia, V. K. (2010). Culture, industrialisation and multiple domains of employees' job satisfaction: a case for HR strategy redesign in India. The International Journal of Human Resource Management, 21(13), 2438-2451. https://doi.org/10.1080/09585192.2010.516 595

Lee, C., Liu, J., Rousseau, D. M., Hui, C., and Chen, Z. X. (2011). Inducements, contributions, and fulfillment in new employee psychological contracts. Human Resource Management, 50(2), 201-226. https://doi.org/10.1002/hrm.20415

Lee, H.-J., Iijima, Y., and Reade, C. (2011). Employee preference for performancerelated pay: predictors and consequences for organizational citizenship behaviour in a Japanese firm. The International Journal of Human Resource Management, 22(10),
2086-2109.

https://doi.org/10.1080/09585192.2011.560 861

*Lepak, D. P., Liao, H., Chung, Y., and Harden, E. E. (2006). A conceptual review of human resource management systems in strategic human resource management research. In J. J. Martocchio (Ed.), Research in personnel and human resource management, vol. 25: 217-271. Greenwich, CT: JAI.

Leung, K., Wang, Z., Zhou, F., and Chan, D. K. S. (2011). Pay disparity in multinational and domestic firms in China: the role of prodisparity norm. The International Journal of Human Resource Management, 22(12), 2575-2592.

https://doi.org/10.1080/09585192.2010.542 769

Lewis, T. (2011). Assessing social identity and collective efficacy as theories of group motivation at work. The International Journal of Human Resource Management, 22(4), 963-980. https://doi.org/10.1080/09585192.2011.555 136

Lin, Z., Trenberth, L., and Kelly, J. (2010). The development and implications of China's employee benefit systems. Asia Pacific Journal of Human Resources, 48(3), 287301. https://doi.org/10.1177/1038411110378958

Lin, Z., Yao, X., and Zhao, Z. (2014). The direct and indirect impact of employee benefits on firm performance in China. Asia Pacific Journal of Human Resources, 52(4), 476495. https://doi.org/10.1111/17447941.12037

Long, R., and Fang, T. (2015). Do strategic factors affect adoption of profit sharing? Longitudinal evidence from Canada. The International Journal of Human Resource Management, 26(7), 971-1001. https://doi.org/10.1080/09585192.2013.872 163

Long, R. J., and Shields, J. L. (2010). From pay to praise? Non-cash employee recognition in Canadian and Australian firms. The International Journal of Human Resource Management, 21(8), 1145-1172. https://doi.org/10.1080/09585192.2010.483 840

Madlock, P. E. (2013). The influence of motivational language in the technologically 
mediated realm of telecommuters:

Motivating language and telecommuters.

Human Resource Management Journal,

23(2), 196-210.

https://doi.org/10.1111/j.1748-

8583.2012.00191.X

Mahajan, A. (2011). Host country national's reactions to expatriate pay policies: making a case for a cultural alignment pay model. The International Journal of Human Resource Management, 22(1), 121-137. https://doi.org/10.1080/09585192.2011.538 973

Majumdar, S. K., Moussawi, R., and Yaylacicegi, U. (2010). Mergers, jobs, and wages in the United States telecommunications industry. Human Relations, 63(10).

Marinova, S. V., Moon, H., and Van Dyne, L. (2010). Are all good soldier behaviors the same? : supporting multidimensionality of organizational citizenship behaviors based on rewards and roles. Human Relations, 63(10).

Mattson, M., Torbiörn, I., and Hellgren, J. (2014). Effects of staff bonus systems on safety behaviors. Human Resource Management Review, 24(1), 17-30. https://doi.org/10.1016/j.hrmr.2013.08.012

McGraw, P. (2015). Changing patterns of compensation and benefits in multinational and Australian companies 1996-2009. Asia Pacific Journal of Human Resources, 53(1), 59-82. https://doi.org/10.1111/17447941.12040

Merriman, K. K. (2014). The psychological role of pay systems in choosing to work more hours. Human Resource Management Review, 24(1), 67-79. https://doi.org/10.1016/j.hrmr.2013.08.008

Merriman, K. K., and Sen, S. (2012). Incenting managers toward the triple bottom line: An agency and social norm perspective. Human Resource Management, 51(6), 851-871. https://doi.org/10.1002/hrm.21491

Miao, Q., Newman, A., Sun, Y., and Xu, L. (2013). What factors influence the organizational commitment of public sector employees in China? The role of extrinsic, intrinsic and social rewards. The International Journal of Human Resource Management, 24(17), 3262-3280. https://doi.org/10.1080/09585192.2013.770 783
Newton, C., Becker, K., and Bell, S. (2014). Learning and development opportunities as a tool for the retention of volunteers: $a$ motivational perspective: Learning and development for volunteers. Human Resource Management Journal, 24(4), 514530. https://doi.org/10.1111/17488583.12040

Ng, T. W. H., and Feldman, D. C. (2014). Community embeddedness and work outcomes : the mediating role of organizational embeddedness. Human Relations, 671).

Ono, H., and Odaki, K. (2011). Foreign ownership, human capital, and the structure of wages in Japan. The International Journal of Human Resource Management, 22(15), 3036-3050. https://doi.org/10.1080/09585192.2011.560 862

Panaccio, A., VanDenBerghe, C. L., and Ayed, A. K. B. (2014). The role of negative affectivity in the relationships between pay satisfaction, affective and continuance commitment and voluntary turnover: a moderated mediation model. Human Relations, 677).

Park, S. M., and Rainey, H. G. (2012). Work motivation and social communication among public managers. The International Journal of Human Resource Management, 23(13), 2630-2660. https://doi.org/10.1080/09585192.2011.637 060

Peltokorpi, V. (2011). Performance-related reward systems (PRRS) in Japan: practices and preferences in Nordic subsidiaries. The International Journal of Human Resource Management, 22(12), 2507-2521. https://doi.org/10.1080/09585192.2011.588 033

*Pepper, A., Gore, J., and Crossman, A. (2013). Are long-term incentive plans an effective and efficient way of motivating senior executives? Long-term incentive plans. Human Resource Management Journal, 23(1), 36-51. https://doi.org/10.1111/j.17488583.2011.00188.x

Perkins, S. J., and White, G. (2010). Modernising pay in the UK public services: trends and implications: Modernising pay in the UK public services. Human Resource 
Management Journal, no-no. https://doi.org/10.1111/j.17488583.2009.00125.X

Redmond, E. (2013). Competency Models at Work: The Value of Perceived Relevance and Fair Rewards for Employee Outcomes: Competency Models at Work. Human Resource Management, 52(5), 771-792. https://doi.org/10.1002/hrm.21560

Reis, F., and Silva, V. P. G. da. (2012). Japanese management and salary productivity: the case of the electronic and automotive industries in Portugal. The International Journal of Human Resource Management, 23(11), 2256-2267.

https://doi.org/10.1080/09585192.2011.605 070

Roch, S. G., Mishra, V., and Trombini, E. (2014). Does Selection Measure Scoring Influence Motivation: One size fits all? International Journal of Selection and Assessment, 22(1), 23-38. https://doi.org/10.1111/ijsa.12054

*Rynes, S., and Gerhart, B. (2000). Compensation in organizations: Current research and practice. San Francisco, CA: Jossey-Bass.

Samnani, A.-K., and Singh, P. (2014). Performance-enhancing compensation practices and employee productivity: The role of workplace bullying. Human Resource Management Review, 24(1), 5-16. https://doi.org/10.1016/j.hrmr.2013.08.013

Sánchez-Marín, G., Baixauli-Soler, J. S., and Lucas-Pérez, M. E. (2010). When much is not better? Top management compensation, board structure, and performance in Spanish firms. The International Journal of Human Resource Management, 21(15), 2778-2797. https://doi.org/10.1080/09585192.2010.528 660

Schmelter, R., Mauer, R., Börsch, C., and Brettel, M. (2010). Boosting corporate entrepreneurship through HRM practices: Evidence from German SMEs. Human Resource Management, 49(4), 715-741. https://doi.org/10.1002/hrm.20366

Schreurs, B., Guenter, H., Schumacher, D., Van Emmerik, I. H., and Notelaers, G. (2013). Pay-Level Satisfaction and Employee Outcomes: The Moderating Effect of Employee-Involvement Climate. Human Resource Management, 52(3), 399-421. https://doi.org/10.1002/hrm.21533

*Schulz, E., Chowdhury, S., and Van de Voort, D.
(2013). Firm Productivity Moderated Link Between Human Capital and Compensation: The Significance of Task-Specific Human Capital. Human Resource Management, 52(3), 423-439. https://doi.org/10.1002/hrm.21537

Selvarajan, T. T., and Cloninger, P. A. (2012). Can performance appraisals motivate employees to improve performance? A Mexican study. The International Journal of Human Resource Management, 23(15), 3063-3084. https://doi.org/10.1080/09585192.2011.637 069

Semykina, A., and Linz, S. J. (2010). Analyzing the gender pay gap in transition economies: How much does personality matter? Human Relations, 63(4), 447-469. http://doi.org/10.1177/0018726709339094

Shaffer, M., Singh, B., and Chen, Y.-P. (2013). Expatriate pay satisfaction: the role of organizational inequities, assignment stressors and perceived assignment value. The International Journal of Human Resource Management, 24(15), 2968-2984. https://doi.org/10.1080/09585192.2013.763 838

*Shane, S. A. (1997). Who is publishing the entrepreneurship research. Journal of Management, 23, 83-95.

Shaw, J. D., and Gupta, N. (2015). Let the evidence speak again! Financial incentives are more effective than we thought: Financial incentives are effective. Human Resource Management Journal, 25(3), 281293. https://doi.org/10.1111/17488583.12080

Singh, S., Mohamed, A. F., and Darwish, T. (2013). A comparative study of performance appraisals, incentives and rewards practices in domestic and multinational enterprises in the country of Brunei Darussalam. The International Journal of Human Resource Management, 24(19), 3577-3598. https://doi.org/10.1080/09585192.2013.777 933

Smith, V. (2010). Review article: enhancing employability; human, cultural, and social capital in an era of turbulent unpredictability. Human Relations, 63(2).

Stone, D. L., Deadrick, D. L., Lukaszewski, K. M., and Johnson, R. (2015). The influence of technology on the future of human resource management. Human Resource 
Management Review, 25(2), 216-231. https://doi.org/10.1016/j.hrmr.2015.01.002

Suleman, F. (2012). The impact of skills and performance on earnings: evidence from retail bankers in Portugal. The International Journal of Human Resource Management, 23(11), 2205-2220.

https://doi.org/10.1080/09585192.2011.610 958

Sun, P.-C., Hsu, W.-J., and Wang, K.-C. (2012). Enhancing the commitment to service quality through developmental and rewarding systems: CSQ consistency as a moderator. The International Journal of Human Resource Management, 23(7), 14621480.

https://doi.org/10.1080/09585192.2011.581 632

Tien, C., and Chen, C.-N. (2012). Myth or reality? Assessing the moderating role of CEO compensation on the momentum of innovation in R\&D. The International Journal of Human Resource Management, 23(13), 2763-2784. https://doi.org/10.1080/09585192.2011.637 059

Unger, D., Sonnentag, S., Niessen, C., and Kuonath, A. (2015). The longer your work hours, the worse your relationship: the role of selective optimization with compensation in the associations of working time with relationship satisfaction and self-disclosure in dual-career couples. Human Relations, $68(12)$.

Villanueva-Flores, M., Valle-Cabrera, R., and Ramón-Jerónimo, M. A. (2015). Perceived compensation discrimination against physically disabled people in Andalusia. The International Journal of Human Resource Management, 26(17), 2248-2265. https://doi.org/10.1080/09585192.2014.985 323

Voigt, E., and Hirst, G. (2015). High and low performers' intention to leave: examining the relationship with motivation and commitment. The International Journal of Human Resource Management, 26(5), 574588. https://doi.org/10.1080/09585192.2014.922 599

Volunteer decisions (not) to leave: reasons to quit versus functional motives to stay. (2012). Human Relations, 65(7).
Wang, G., and Singh, P. (2014). The evolution of CEO compensation over the organizational life cycle: A contingency explanation. Human Resource Management Review, 24(2), 144-159. https://doi.org/10.1016/j.hrmr.2013.11.001

Wang, M.-C., and Chiu, S.-T. (2013). The function of independent directors with different payoff rules: the issue of shareholder activism. The International Journal of Human Resource Management, 24(15), 3020-3030. https://doi.org/10.1080/09585192.2013.767 063

Wang, T., Zhao, B., and Thornhill, S. (2015). Pay dispersion and organizational innovation: the mediation effects of employee participation and voluntary turnover. Human Relations, 68(7).

Williams, C. C. (2010). Beyond the formal/informal jobs divide: evaluating the prevalence of hybrid "under-declared" employment in south-eastern Europe. The International Journal of Human Resource Management, 21(14), 2529-2546. https://doi.org/10.1080/09585192.2010.523 573

*Willems, J., Huybrechts, G., Jegers, M., Vantilborgh, T., Bidee, J., and Pepermans, R. (2012). Volunteer decisions (not) to leave: Reasons to quit versus functional motives to stay. Human Relations, 65(7), 883-900. http://doi.org/10.1177/0018726712442554

Woodhams, C., Lupton, B., Perkins, G., and Cowling, M. (2015). Multiple Disadvantage and Wage Growth: The Effect of Merit Pay on Pay Gaps. Human Resource Management, 54(2), 283-301. https://doi.org/10.1002/hrm.21692

Wu, P., Chen, T., and Leung, K. (2011). Toward performance-based compensation: a study of the gaps between organizational practices and employee preferences with regard to compensation criteria in the state-owned sector in China. The International Journal of Human Resource Management, 22(9), 19862010. https://doi.org/10.1080/09585192.2011.573 974

Xavier, B. (2014). Shaping the future research agenda for compensation and benefits management: Some thoughts based on a stakeholder inquiry. Human Resource 
Management Review, 24(1), 31-40. https://doi.org/10.1016/j.hrmr.2013.08.011

Yanadori, Y. (2011). Paying both globally and locally: an examination of the compensation management of a US multinational finance firm in the Asia Pacific Region. The International Journal of Human Resource Management, 22(18), 3867-3887. https://doi.org/10.1080/09585192.2011.610 972

Yanadori, Y., and Kang, S.-C. (2011). Intra-firm differentiation of compensation systems: evidence from US high-technology firms: Intra-firm differentiation of compensation systems. Human Resource Management Journal, 21(3), 236-257. https://doi.org/10.1111/j.17488583.2010.00160.x

\section{ABOUT THE AUTHORS}

Nereida Hadziahmetovic, email: nereida.hadziahmetovic@ibu.edu.ba

Dr. M. Sait Dinc is an Associate Professor of Management and Lecturer at the Faculty of Economics and Social Sciences, International Burch University, Bosnia and Herzegovina. His current research interests include organizational behavior, human resource management, and ethics in management. He has published several peer-reviewed articles in journals and numerous papers at national and international conferences. $\mathrm{He}$ is currently in editorial board of two international journals.

M.A. Nereida Hadziahmetovic is a senior teaching assistant in Management Department of the Faculty of Economics and Social Sciences at International Burch University. She is currently a PhD candidate, and her research interests include human resources management, knowledge management, and organizational behavior. She has published several peer reviewed articles in international journals. She is also editorial assistant of Journal of Economics and Social Sciences.

Ms. Kanita Jahic is an accounting associate at Jitasa LLC Sarajevo, a Bachelor of Science in Financial Management, and a current MBA student at the International Burch University in Sarajevo. Her research interests cover the position of youth and its perspectives in Bosnia and Herzegovina, domestic industry and the development of the country, as well as general accounting and managerial topics. As a recent graduate, she is currently approaching the academic research processes. 